\title{
Silence Matters: A survey of the right to silence in the summary jurisdiction of New South Wales
}

\section{Introduction and Background}

'The right to silence', according to the Australian High Court, 'is that right which provides the fundamental bases for the common law rules governing the admissibility and reception of confessional evidence' (Aronson and Hunter, 1995, 326). These common law and, in NSW, statutory rules surrounding confessional evidence are sometimes said to contain a set of related rights and freedoms including: i) voluntariness of confessional evidence; ${ }^{1}$ ii) the presumption of innocence, ${ }^{2}$ iii) the burden and standard of proof ('beyond reasonable doubt' $){ }^{3}$ iv) the protection against self-incrimination; ${ }^{4} \mathrm{v}$ ) a prohibition against any adverse inference being drawn against the accused from their silence 'during official questioning', ${ }^{5}$ and vi) the right to counsel. ${ }^{6}$ It is the third, fourth and fifth of these "silence rights" ${ }^{7}$ (Dixon and Cowdery, 2013) - the burden and standard of proof and the protection or 'privilege' against self-incrimination both during official questioning and at trial - with which this study is mostly concerned, by seeking to show empirically how a selection of these silence rights work in practice throughout the criminal process. ${ }^{8}$

\footnotetext{
${ }^{1}$ NSW Law Reform Commission Report 95, 31; Evidence Act 1995 (NSW), s. 84; $R$ v Swaffield; Pavic v The Queen [1998] HCA 1; 192 CLR 159; 151 ALR 98; 72 ALJR 339 (20 January 1998).

${ }^{2}$ NSW Parliamentary Library Briefing Paper 12/2000 Pre-Trial Defence Disclosure: Background to the Criminal Procedure Amendment (Pre-Trial Disclosure) Bill 2000, Chapter 3. The Evidence Act, s. 89 (1)(a); LEPRA, s. 122(1)(a).

${ }^{3}$ Ibid, Evidence Act, ss. 141(1) and 3 (definition of 'case');

${ }^{4}$ Ibid, Evidence Act, s. 89(1)(a); Law Enforcement (Powers and Responsibilities) Act 2002 (NSW) ('LEPRA'), s. 122(1)(a).

${ }^{5}$ See Petty and Maiden v R (1991) 173 CLR 95, 90, codified by the Evidence Act, s. 89(1)(a); and modified by Weissensteiner $v R$ (1993) 178 CLR 217.

${ }^{6}$ LEPRA 2002, s. 22(1); $R$ v Dietrich (1992) 177 CLR 292, [1992] HCA 57.

${ }^{7}$ The definition of 'the right to silence' and the use of the term, 'silence rights' is contested within the literature on evidence law and is the subject of ongoing debate. This debate is explored later in the article, see pp. 13-16.

${ }^{8}$ The author thanks Professor of Public Statistics, James Brown and Public Statistics PhD candidate, Torrington Callan, at the University of Technology Sydney (UTS), for their assistance in visualising the data used in this article.
} 
The purpose of this project is to contribute to the scholarly literature surrounding the effects of the right to silence on conviction within criminal and summary jurisdictions, particularly for marginalised or 'vulnerable' criminal defendants. This study builds on similar empirical work undertaken in respect to the right to silence in the United Kingdom and Singapore between the 1970s and early 2000s (see, for instance, Cross, (1971); Jackson, (1991); Bucke, Street and Brown (2000); Phillips and Brown, (1998), Yeo (1983); Tan (1997); O’Mahony, (1997); Jackson, Quinn and Wolfe (2000); Coldrey, (1991); Leng, (1993)). The latter predominantly focused on the effect of introducing 'adverse inference' provisions into the law of criminal evidence in these jurisdictions (laws allowing judges and juries to draw inferences of guilt against an accused person because they exercised their right to silence). ${ }^{9}$ No empirical scholarly work has been published in respect to this issue in Australia. Accordingly, the findings of this study deepen understandings of how silence is exercised throughout the criminal process in a summary Australian jurisdiction that is largely unburdened by adverse inference provisions. In this respect this study also provides a useful comparator or control study to the existing international scholarship. But its aims are broader. This study focuses its enquiry on gaps identified by the largest empirical study on the issue, conducted by Bucke and colleagues (et al. 2000), including: i) the extent to which silence laws affect marginalised groups (Bucke et al., (2000), p. 76); ii) how silence rights operate in respect to charges in which silence is more clearly an issue (such as those involving a fault or mens rea element, as opposed to strict liability offences) (Bucke et al., (2000), p. 67); and iii) the ways in which decision-making by suspects and defendants operates within the criminal process (Bucke et al., (2000), p. xiv). Such information allows stakeholders and policy makers greater insight into the significance of silence rights, especially their effects. As

\footnotetext{
${ }^{9}$ In practise, the provisions mean that when law enforcement officials administer a caution to a suspect by telling them that they have the right to remain silent and that anything they say may be recorded and used in evidence against them, officials must, in addition, advise the suspect that their silence or failure to answer questions may be used against them at their trial by a judge or jury to infer guilt: Evidence Act, s. 89A.
} 
importantly, it provides researchers and commentators with greater evidence for enhanced explanation and understanding of pre-trial criminal procedure, not only between criminal jurisdictions (such as between jurisdictions that maintain adverse inference provisions and those that do not) but also between criminal and regulatory jurisdictions that frequently dispense with the right to silence (Stewart, (2016), p. 100; Comino, (2014)). As a recent Australian Law Reform Commission Report on the subject found, 'evidence regarding the effect' of the right to silence 'is not easy to come by' (ALRC, (2016), p. 320). ${ }^{10}$

The empirical literature on silence rights is polarised by a debate about the effect of adverse inference provisions. On one side, academic commentators and civil libertarian lawyers have collected data that appears to downplay the significance of the right to silence, perhaps in order to save it from erosion by adverse inference provisions (Bucke et al., (2000); Jackson et al., (2000); and Leng, (1993)). They have shown that the right to silence is asserted infrequently with little effect on conviction. On the other side of the debate are police and conservatives who have collated empirical data showing a much higher incidence of silence use (Association of Chief Police Officers (ACPO), (1993), cited in Bucke et al., (2000), p. 2; Grant, (2018); Smith, (2013), p. 2). They argue that silence frustrates the investigation process, necessitating adverse inference provisions that coerce the guilty to confess to police (Association of Chief Police Officers (ACPO), (1993), cited in Bucke et al., (2000), p. 2; Grant, (2018); Smith, (2013), p. 2). Following the implementation of adverse inference provisions in Britain and Ireland by the Thatcher and Major governments, academics such as Bucke et al., (2000) pointed predominantly to official statistics to suggest that the overall rate of convictions did not increase in the years following the introduction of adverse inference laws (pp. 65-72; see also, Jackson et al., (2000)). Evidence specialist, John Jackson, made

\footnotetext{
${ }^{10}$ A Victorian Parliamentary Committee reached a similar conclusion in 1999 (s. 2.3.4).
} 
similar findings in Northern Ireland in the early 1990s, concluding that 'the right of silence has been regarded as a sacred cow, but the lesson for those who view abolition or curtailment of the right as a panacea for the conviction of offenders is that they may be just as guilty of putting their faith in a sacred cow' (Jackson et al., (1991), p. 416). For these commentators, adverse inference provisions have simply translated to 'more cock and bull stories', rather than more confessions (Bucke et al., (2000), p. 35; Jackson et al., (2000)). Nevertheless, Bucke et al. (2000) have suggested that more work is needed to clarify precisely how silence works throughout the criminal process and which groups may be disadvantaged by restrictions upon it (pp. 67, 76) - disadvantages which may not necessarily appear in large aggregated national data sets.

Indeed, more recent academic commentary has pointed to problems with the use of these official data sets. The late evidence scholar, Mike Redmayne (2008), for instance, observed that the studies in England and Ireland were conducted too soon after the introduction of the adverse inference laws to properly quantify their effect and that these studies overlooked the impact of recently introduced plea discount legislation (pp. 1081-1083). Redmayne (2008) also cited English conviction rates from years other than those cited by the major English study to show a substantial increase and variance in convictions following the implementation of adverse inference provisions (pp. 1081-1083). A similar increase in the conviction rate was observed in Singapore following the introduction of adverse inference provisions in that jurisdiction (Meng Heong Yeo, (1983)). Another nuanced view of the official statistics, expressed by evidence scholar, Owusu-Bempah (2017), cited the combined findings of two English studies conducted both before and after the introduction of adverse inference laws (pp. 133-134). Owusu-Bempah (2018) concludes that interference with silence laws disproportionately impact black suspects who rely on silence rights more frequently than 
other suspects (pp. 133-134). ${ }^{11}$ Indeed, despite the apparent null hypothesis shown by the official English and Northern Irish statistics, a large cohort of scholars (some of whom themselves helped collate the statistics), has continued to oppose the 'watering-down' of silence rights, for instance, by the introduction of adverse inference provisions or other forms of compulsion. Most such researchers explicitly support stronger use of silence rights in the interests of ensuring that criminal procedure operates in accordance with democratic principles (see, for instance, Jackson, (2001); Birch, (1999); Dennis (1995); Redmayne, (2008); Hocking and Manville, (2001)). They have done so, however, largely in the absence of solid evidence. The results of investigation reported in this paper make a fresh and significant contribution to the evidence required to support the evidence required to support the claim that the use of silence is a critical requirement for democratic criminal process. Nevertheless, it is beyond the scope of this article to explain how and why this is the case. Such an explanation requires further in-depth qualitative study, not only comparing those who exercise or waive their right to silence; but also study of court process and complexities in which such rights are exercised or waived. Combined with the results of quantitative investigation, as presented and analysed in this paper, such findings form the necessary empirical basis for explaining how and why silence rights are foundational to democratic criminal process. Accordingly, the present study may be understood as one piece of a complex puzzle in determining how the use of silence works and with what effects, not only for individuals but for the democratic integrity of the criminal process.

This study examines the operation of silence rights in the summary criminal jurisdiction of New South Wales (NSW) - Australia's most populous State and a jurisdiction in which 93\%

\footnotetext{
${ }^{11}$ Owusu-Bempah cites the combined findings of Phillips and Brown (1998) and Bucke et al. (2000) to show that black suspects asserted their right to silence in $21 \%$ of cases before the introduction of adverse inference laws (compared to 13 and 8 per cent respectively of Asian and white suspects). After the introduction of the laws, the figure was 12 per cent (compared with 8 and 9 per cent of Asian and white suspects)).
} 
of the State's criminal matters are heard (Australian Bureau of Statistics (ABS) (2019)). ${ }^{12}$

The aims here are twofold: first, to demonstrate the frequency with which silence rights are used by marginalised criminal defendants $;{ }^{13}$ and, second, to identify their effect on criminal conviction for those defendants. The findings from this study show that silence rights are asserted throughout the criminal process in a significant majority of summary criminal cases. These results further indicate that silence rights play a significant role in mitigating the effects of the criminal law, in particular, the impact of convictions upon this marginalised group of defendants.

While adverse inference provisions have been introduced relatively recently into the indictable jurisdiction of NSW, these laws do not operate at the level of summary jurisdiction in which this study was conducted. ${ }^{14}$ Together with the expansive size of the jurisdiction, the absence of adverse inference provisions in this jurisdiction was a key reason for its selection as a site of study. This situation renders the results of this study useful as a control test for future research on the use and effects of silence rights for vulnerable criminal defendants in other jurisdictions, as well as the operation of powers of compulsion (for instance, against 'white collar' crime) in various regulatory jurisdictions. Nevertheless, silence rights within this jurisdiction are affected to a minor degree by the power of a court to compel a defendant to answer questions at trial, provided a defendant agrees to give evidence (Heydon, (2018), pp. 25175-25180). ${ }^{15}$ Yet the data encountered in this study, as well as the opinion of

\footnotetext{
${ }^{12}$ In 2018, the population of New South Wales was around 8 million: NSW Government, 2019: https://www.nsw.gov.au/about-new-south-wales/population/.

13 The concept of 'marginalisation' together with the identity of the particular social group that is the subject of this research are discussed on pp. 9-10.

${ }^{14}$ Evidence Act, s. 89A. Similar laws affecting silence in the NSW indictable jurisdiction include the Criminal Procedure Act 1986 (NSW), ss. 136-143 (amended by the Criminal Procedure Amendment (Pre-Trial Defence Disclosure) Bill 2013), together with the Justice Legislation Amendment (Committals and Guilty Pleas) Act 2017 (NSW), which are designed to encourage early 'guilty' pleas through mandatory case conferencing. The former requires the defence to disclose its case (facts and argument on which it intends to rely at trial) to the prosecution before trial (see Criminal Procedure Act, s. 143).

${ }^{15}$ Evidence Act, ss. 128(4) and (10); Chong v CC Containers Pty Ltd (2013) 49 VR 202.
} 
Australian evidence scholars, suggest that it is seldom used (Heydon, (2018), p. 25180). ${ }^{16}$ In this respect, summary NSW courts appear to defer to common law protections of silence rights (Heydon, (2018), p. 25180) ${ }^{17}$ that are largely consistent with those contained within the International Covenant on Civil and Political Rights 1966 (UN) (Article 14). ${ }^{18}$

\section{Method, Samples and Data}

There are a variety of ways to measure silence rights. Past studies have either quantified the practices of defendants within a sample group (see, for instance, the approaches of Leng, (1993), Phillips and Brown, (1998), Jackson, (1991)(b)), or relied upon official statistics to generalise about a particular outcome (for instance, Bucke et al., (2000) and Jackson et al., (2000)). Given the objectives of this study (to assess the use of silence rights by marginalised defendants in NSW), together with problems associated with the use of official statistics outlined above, this study measured silence by reference to a sample group of defendants represented by a publicly funded agency reserved for very low-income clients - Legal Aid NSW (Legal Aid). A further advantage of this method is that it allows for measurement of silence rights over time, throughout the criminal process, from the investigation stage to pretrial stage to trial stage. By contrast, most other studies have only examined the investigation stage while relying on official statistics to document general rates of conviction and guilty pleas. In this respect the method used here is similar to one of the earliest studies by Jackson et al. ((1991)(b), Appendix C) which traced the use of silence rights in respect to 121 specific matters. The present study is larger, closely examining 350 different matters.

\footnotetext{
${ }^{16}$ No use of this power was encountered during this study.

${ }^{17}$ See also, X7 v Australian Crime Commission (2013) 248 CLR 92, [124] per Hayne and Bell JJ, Kiefel J agreeing; Petty and Maiden v R (1991) 173 CLR 95, per Mason CJ, Deane, Toohey, and McHugh JJ, at [2] the High Court said that the right to silence was 'a fundamental rule of the common law'.

${ }^{18}$ In particular, ICCPR, Art. 14(2) (the presumption of innocence); and Art. 14(3)(g) (the burden of proof, right to silence and privilege against self-incrimination).
} 
The study presented here used both quantitative and qualitative methods. The quantitative component of the study sought to measure the use and effect of silence rights as recorded in summary jurisdiction Legal Aid files. With the assistance of Legal Aid, ${ }^{19}$ the author gained access to a large repository of recently closed Legal Aid files from between January 2016 to July $2018 .{ }^{20}$ Well in excess of 1000 files were examined. This selection was eventually narrowed to the final 350 files or 1008 criminal charges from the Haymarket, Parramatta and Liverpool offices of Legal Aid. Subject to certain exceptions - discussed below - files were selected from the Legal Aid archive at random (using 'random probability sampling' (Bryman, (2016), pp. 171-195)) and the results quantified.

Qualitative 'content analysis' (Bryman, (2016), pp. 285-307) was used to extract primary data on the use and effects of silence rights over time from each legal aid file. Documents subjected to content analysis within each file included the file cover (indicating the outcome of the matter, number of mentions and type of court appearance), police facts and charges, client instructions to legal representatives and solicitor notes on court practice, including notes on plea bargains or 'representations', court submissions and hearing proceedings. These documents are usually included within each file as a matter of professional practice and internal Legal Aid protocol. In some cases, missing results were obtained from the NSW Attorney-General's Department Local Court hotline. ${ }^{21}$ The content analysis applied key

\footnotetext{
19 The author thanks Legal Aid NSW, the Practice Managers of the Summary Criminal Teams at the Haymarket, Parramatta and Liverpool offices, as well as the NSW Law Society and the NSW Attorney-General's Department.

${ }^{20}$ Data obtained during this study is protected by legal professional privilege (Evidence Act 1995 (NSW), ss. 117-129). Ethics approval to peruse this information for research purposes was pre-provided by Legal Aid clients through the standard Legal Aid retainer agreement, as well as a confidentiality agreement executed between the author and Legal Aid NSW. Further ethics approval was sought and obtained by the author after approaching the NSW Law Society, NSW Attorney-General's Department, the UTS Ethics Committee and the Dean of Research at UTS Law School. All data has been deidentified prior to publication and is now stored securely and privately.

${ }^{21}$ As a matter of NSW Local Court Registry policy, outcomes were only disclosed in respect to matters that were determined within a fortnight of the date of inquiry and heard in open court.
} 
indicators or criteria for identifying the use and effects of the right to silence throughout three key stages of the criminal process: the investigation stage; pre-trial or mention stage; and the final determination, 'trial' or 'courtroom' stage. Indicators used for identifying use of the right to silence included waivers and assertions of the right to silence during each of the three stages (although partial assertions and denials, discussed in more detail below, were also counted). The results of each matter - conviction or dismissal of charges - were applied to identify the effects of using or not using the right to silence.

Where the source of this data was a means-tested public defenders' office, the findings of this study reflect the use of the right to silence by a specific social group of marginalised criminal defendants. Social exclusion or marginalisation in this context refers to a process by which certain people are prevented from accessing similar social and economic opportunities and resources available to members of other social groups, due to unequal social relationships such as class, race and/or disability (Silver, (1994); Honneth, (1996)). All defendants within the sample population for this study were subject to a means test, restricting legal assistance to people who earn less than $\$ 400$ per week and have minimal assets (Legal Aid NSW, (2018a)). A significant social outcome of the Legal Aid means test is that Legal Aid clients are typically working-poor and unemployed people. Around one-in-six Legal Aid clients selfidentify as Aboriginal (Legal Aid NSW, (2018b), p. 10). Although not quantified in this study, nor by Legal Aid, a further striking indicator of marginalisation that emerged during the content analysis phase of this study was the number of Legal Aid defendants suffering disability, most commonly mental illness. This observation accords with a finding by the NSW Judicial Commission that $80 \%$ of NSW prisoners suffer mental illness (Gotsis and 
Donnelly, (2008), pp. 2-3). ${ }^{22}$ Added to the overall social significance of the results from this study is the fact that Legal Aid represents around 57\% of criminal defendants that pass through the NSW Local Court system. ${ }^{23}$ Put differently, a majority of criminal defendants in this jurisdiction are, at the very least, significantly economically marginalised.

Largely excluded from analysis were matters such as strict liability offences (predominantly traffic offences), as well as those that involved diversion to the NSW Drug Court or a mental health outcome. Traffic matters were mostly excluded for two reasons: first, they rarely appear in the sample due to frequent (but not complete) exclusion by a Legal Aid means test (2018a); ${ }^{24}$ and second, they rarely involve issues of silence rights due to their status as strict liability or 'regulatory' offences. Strict liability offences do not require proof of a mental element of an offence and hence, are rarely challenged by defendants, for example by reliance on silence rights. In this respect, the sample in this study was guided by the contention raised by Bucke et al. (2000) that silence rights matter more in trials which involve issues of fault. ${ }^{25}$ As the analysis section explains in more detail below, where traffic offences account for around 40 per cent of matters in this jurisdiction annually, ${ }^{26}$ their exclusion from analysis accounted for a significant difference in the use and effects of silence compared with previous studies and official statistics that counted such offences.

Diversionary and mental health matters were also excluded from analysis where they depart

\footnotetext{
${ }^{22}$ Levels of mental illness occur at a rate of $31 \%$ in the general Australian population (Gotsis and Donnelly, (2008), pp. 2-3).

${ }^{23}$ There are two statistics used to obtain this figure. The Legal Aid NSW Annual Report, shows that substantive Legal Aid grants and duty lawyer services within the criminal jurisdiction numbered 190,124 in the year 20162017 ((2018b), pp. 164-165). Meanwhile, the Local Court of New South Wales Annual Review 2017, shows that the number of matters finalised by the Local Court in that year was 333,564 ((2018), p. 12). The figure of 190,124 is $57 \%$ of 333,564 .

${ }^{24}$ The specific wording of the policy excludes legal assitance for matters other than those requiring 'minor assistance'. Traffic offences are mostly punishable by 'fine only' and therefore legal representation is excluded where these matters require only 'minor (legal) assistance' (Legal Aid NSW, (2018a)).

${ }^{25}$ Bucke et al., p. 67.

${ }^{26}$ ABS, Criminal Courts, Australia 2017-2018 dataset for NSW (2019), 4513.0.
} 
from the conventions of criminal procedure. ${ }^{27}$ As a result, the array of offences surveyed here mostly contained fault elements and were punishable by imprisonment, e.g. drug, property and assault matters. Unlike strict liability offences, these offences typically provided a defendant with a choice as to whether to confess, or plead 'guilty' immediately, or to assert the right to silence throughout the criminal process.

It must be acknowledged that this study and its methods suffer certain limitations. The study does not investigate, for instance, why individual defendants exercise silence rights (for example, due to a sense of shame or guilt, or the strength of the prosecution or defence case). In this sense, the results are limited to explaining how silence operates as a factor within the criminal process in respect to a particular sample group. In this respect, silence rights might also be said to constitute a mere vehicle, within the criminal process, by which a range of further processes occurs. Socio-legal scholars such as Duff (2007, pp. 191-3) and Lacey $(2012,33)$, for instance, have insisted that law and process only ever exist as a vehicle to administer particular social outcomes and is always contingent upon social processes extrinsic to the law that endow legal process with meaning. In this respect, the results outlined here are indicative only. They do not claim to show a causative relationship between silence and conviction. Given the multiplicity of human interactions, chance occurrences and unpredictable emotions involved with the criminal law, it is doubtful as to whether any study could ever quantify abstract legal process with complete accuracy. Rather, the findings presented here represent strong patterns, associations and trends that establish a significant correlation between silence and conviction mostly using standard quantitative methods within the social sciences.

\footnotetext{
${ }^{27}$ Drug diversion in NSW requires a routine plea of guilty in return for rehabilitative drug treatment (Drug Court Act 1988 (NSW), s. 5(1)(c)), while mental health orders follow an alternative path to a finding of guilt (see, Mental Health (Forensic Provisions) Act 1990 (NSW), s. 32.
} 
A further limitation arising from the use of criminal legal files is that charges have been laid in every matter. In this sense, the sample excludes from consideration how silence operates at the stage of arrest and investigation for prospective Legal Aid clients who have been arrested and released from police custody without charge. Insight into the relatively low numbers of suspects arrested and released without charge nevertheless exists in the English studies of Phillips and Brown (1998) and Bucke et al. (2000). In this respect, however, these studies do not clearly distinguish between matters in which an interview was refused outright by a suspect and those in which an interview was undertaken to which the suspect responded without comment (a 'no comment interview') to every answer. Indeed, such a distinction could alter the outcome of the results. This study, by comparison, does incorporate consideration of such a distinction.

\section{Understanding the Right to Silence}

In attempting to justify the right to silence, commentators have sometimes disagreed about the definitional breadth of silence rights. Such disagreement complicates empirical measurement of silence rights. Redmayne (2007), for example, has argued that the related privilege against self-incrimination (exercised in court) was technically distinct from the right to silence (exercised during the investigation stage), as well as the presumption of innocence and burden of proof (requiring the prosecution to prove its charge); that it existed chiefly to allow citizens to dissociate themselves from a prosecution; that its use contains too many variables to accurately assess via empirical analysis; and that it should therefore be defined narrowly. Redmayne's 'narrow' definition has since been challenged by evidence law commentator, Hamish Stewart (2016), who suggests that there is in fact, 'an underlying normative connection between the presumption of innocence, the privilege against self- 
incrimination, and the requirement that the state make its case without the active testimonial participation of the accused' and that 'the privilege against self-incrimination carries on through the entire criminal process as a concomitant of the presumption of innocence' (p. 98). This broad view appears to be supported by a range of commentators as well as the reading given to ICCPR, Art. 14 by the European Court of Justice. ${ }^{28}$ Indeed, the narrow view that silence rights are simply 'too complex' to be analysed empirically has little validity in the face of numerous international scholars' (discussed above) empirical research on the right to silence and related 'silence rights'.

In the measurement of silence, some studies have relied on simply a police interview or 'narrow view', while others have used the entire case, taking a 'broad view' (Phillips and Brown (1998), p. 74; Jackson et al. (1991)). On this point, Bucke et al. (2000) acknowledge that measurement of 'the right to silence' throughout the case implicates other related rights such as the presumption of innocence and burden of proof (pp. 57-59). In addition to supporting the broad view, Stewart also indicates his support for its empirical measurement, contending that "empirical generalisations about the value of interrogations or about how people behave when under investigation' have much to offer, precisely because 'underlying' silence rights is 'an empirical conception of the typical level of human fortitude, that is a set of assumptions about the ways in which detainees are or are not vulnerable to the pressure of interrogation and about what can be done to ensure their choice to speak is a free one,' as well as 'a belief that detainees are in general a useful source of reliable information about the crime' (p. 100).

\footnotetext{
${ }^{28}$ See Duff (2007); and Hocking and Manville (2001). The decisions of the ECJ as well as the European Charter position were discussed by the Privy Council in Brown v Stott [2003] 1 AC 681.
} 
It is on this basis that this study takes a broad view of 'silence rights', mapping their use and effects throughout three key phases of the criminal process - the investigation, pre-trial and determination stages. In doing so, this project analyses the use of the 'right to silence' by suspects during the investigation stage of proceedings when police are required to caution a suspect and offer the suspect a police interview. Next, it assesses the use of the presumption of innocence, burden of proof, together with the privilege against self-incrimination at the pre-trial or 'mention stage' when defendants first attend court. It is at this point that defendants may elect to confess to a charge by waiving their silence rights and pleading 'guilty'.

Alternatively, defendants at this point may contest a charge by pleading 'not guilty', invoking their silence rights in the form of the presumption of innocence, burden of proof and privilege against self-incrimination. In practical terms, this usually means that a defendant simply remains silent in the weeks and months leading up to a summary trial or 'hearing date', in turn requiring the prosecution to prove its case against them at the hearing. Finally, the study assesses the use of the privilege against self-incrimination by defendants in a small number of cases that ran to summary trial. The frequency of use of silence rights throughout these three stages is then compared with outcomes to ascertain the 'effects' of silence. Outcomes are measured by assessing any resulting convictions, non-convictions or plea bargains.

Complicating the broad view of silence rights, however, is the fact that assertions of silence rights are sometimes merely partial or used in combination with their waiver. For example, a suspect may make admissions to only one or two police questions. Alternatively, after refusing a police interview a defendant may nevertheless plead guilty or give evidence in 
court. ${ }^{29}$ For practical purposes, the defendant waives the privilege, but nevertheless asserts the burden and standard of proof by pleading 'not guilty', requiring the prosecution to prove its case at hearing beyond reasonable doubt. It follows that any mapping process involving silence rights must account for their assertion both over time or, throughout the process, as well as, in combination with their waiver - hence the classification of the criminal process into three stages in this study. A further design feature of this study that accounts for the nebulous nature of the silence rights is the separate measurement of 'denials' in police interviews as distinct from confessions and declined interviews during the investigation stage. ${ }^{30}$ By making a denial, a defendant technically waives the right to silence. However, the logical implication of a denial is actually to assert other freedoms that flow from the right to silence, such as the presumption of innocence and burden of proof. By extension, these silence rights require the prosecution to prove its case to the requisite standard of proof. It is for this reason that waivers are measured in this study as a logical separate category of silence rights. In this way, they can easily be added to or subtracted from more conventional measures of silence rights, depending on whether the reader adopts a narrow or broad view of silence rights. As indicated above, the broad view is preferred in this study.

\section{Frequency of Use}

Eight key measures were used to assess the frequency of silence rights. The first involved comparing the number of admissions and non-admissions during the investigation stage. This measure provides for the frequency of assertions and waivers of the right to silence during the

\footnotetext{
${ }^{29}$ Evidence Act, s. 128(10) abolishes the privilege for defendants who give evidence at trial: see, Cornwell $v R$ (2007) 231 CLR 260, provided that a defendant chooses to enter the witness box: Chong v CC Containers Pty Ltd (2013) 49 VR 202.

${ }^{30}$ Denials made during the investigation stage are commonly classified by the law of evidence as, 'admissible hearsay' evidence or, 'previous representations that are not adverse to a person's interest' (Odgers, (2018), p. 598, p. 611); see also, Adam v The Queen (2001) 207 CLR 96. In this case, 'denials' were classified as, 'a previous representation that is not adverse to a person's interest'.
} 
investigation stage. Admissions here included legally admissible post-arrest confessions, either upon arrest or during police interviews. ${ }^{31}$ Non-admissions, on the other hand, included 'no comment' police interviews and declined interviews. As discussed, investigation stage 'denials' were counted separately. Suspects who made partial admissions were counted as either making admissions or denials (depending on whether they denied the charge) but were wholly excluded from the category of assertions of the right to silence.

The second measure counted 'guilty' and 'not guilty' pleas throughout the initial courtroom or 'mention' stage of proceedings to assess the frequency of assertions and waivers of both the privilege against self-incrimination and burden of proof during the mention stage. Similarly, the third measure counted final and changed pleas (from 'not guilty' to 'guilty') at the sentencing or hearing stages of proceedings. The fourth measure involved a simple count of the number of charges in which defendants gave evidence at hearing (measure 4), assessing the frequency of assertions and waivers of the privilege against self-incrimination. Measure 5 counted charges in which evidence given during an interview was repeated at hearing, assessing the frequency of 'denials' or charges in which waivers of the right to silence and privilege against self-incrimination were combined with assertions of the burden of proof.

The sixth measure ('total assertions' and 'total waivers') involved adding up the number of charges in which any assertion or waiver of either the right to silence, burden or standard of proof, or privilege against self-incrimination was made at any stage throughout the criminal process, including combined assertions and wavers. The category of 'total assertions'

\footnotetext{
${ }^{31}$ See, Evidence Act, ss. 81-90 (admissions are defined by s. 3 of the Act as a 'previous representation', made by a criminal defendant that is 'adverse to the person's interest in the outcome of the proceeding').
} 
included: silence upon arrest, declining or refusing to answer questions during a police interview, as well as pleading 'not guilty', or refraining from giving evidence at hearing. 'Total waivers' included confessions and admissions (either at the scene, upon arrest or during a police interview), pleas of 'guilty', and giving evidence at hearing. ${ }^{32}$ Denials were tallied separately. ${ }^{33}$

The seventh measure of frequency involved the number of 'consistent assertions' and 'consistent waivers' of silence rights. Consistent waivers included matters in which defendants completely or consistently waived the right silence by confessing during the investigation stage and pleaded 'guilty' during the pre-trial stage, thereby dispensing with burden of proof. Consistent assertions were those matters in which defendants completely asserted the privilege against self-incrimination, together with the burden and standard of proof, at all stages of the criminal process - declining an interview, pleading 'not guilty' and proceeding to hearing without giving evidence.

Measure eight involved tallying charges and matters resolved by representations. Representations are a form of charge bargaining, usually requiring the negotiation of multiple charges between defence and prosecution, i.e. the withdrawal of some charges in exchange for a 'guilty' plea to others. The related nature of silence rights across multiple charges within a given matter in which representations are made means that, in this study, representations were counted by 'matters', rather than charges. A range of sub-measures was used to count the frequency of the use of silence rights among these matters.

\footnotetext{
${ }^{32}$ As units of analysis, 'total assertions' and 'total waivers' contain overlapping variables and are only comparable by univariate analysis.

${ }^{33}$ Although given the small number of denials, their addition to either category of analysis would not make a significant difference.
} 
Measure 1: Silence during the investigation stage

During the investigation stage, 364 charges $(36 \%)$ were the subject of admissions or waivers. A further 89 charges (8.8\%) saw defendants give an interview in order to deny the charges waiving the privilege while asserting the burden and standard of proof. In a majority of 555 charges $(55 \%)$, however, defendants made no admissions, asserting the privilege instead. These figures are illustrated in the first frequency plot in Figure $A,{ }^{34}$ below.

If denials are added to assertions, we can see that silence rights were invoked across an overwhelming majority of 644 charges (64\%) during the investigation stage. In this respect, assertions of silence rights during the investigation stage occurred ten per more frequently than waivers of silence rights during this stage of the criminal process.

\footnotetext{
${ }^{34}$ All statistical images and graphs contained within this article were produced using the statistical imaging program, SPSS.
} 


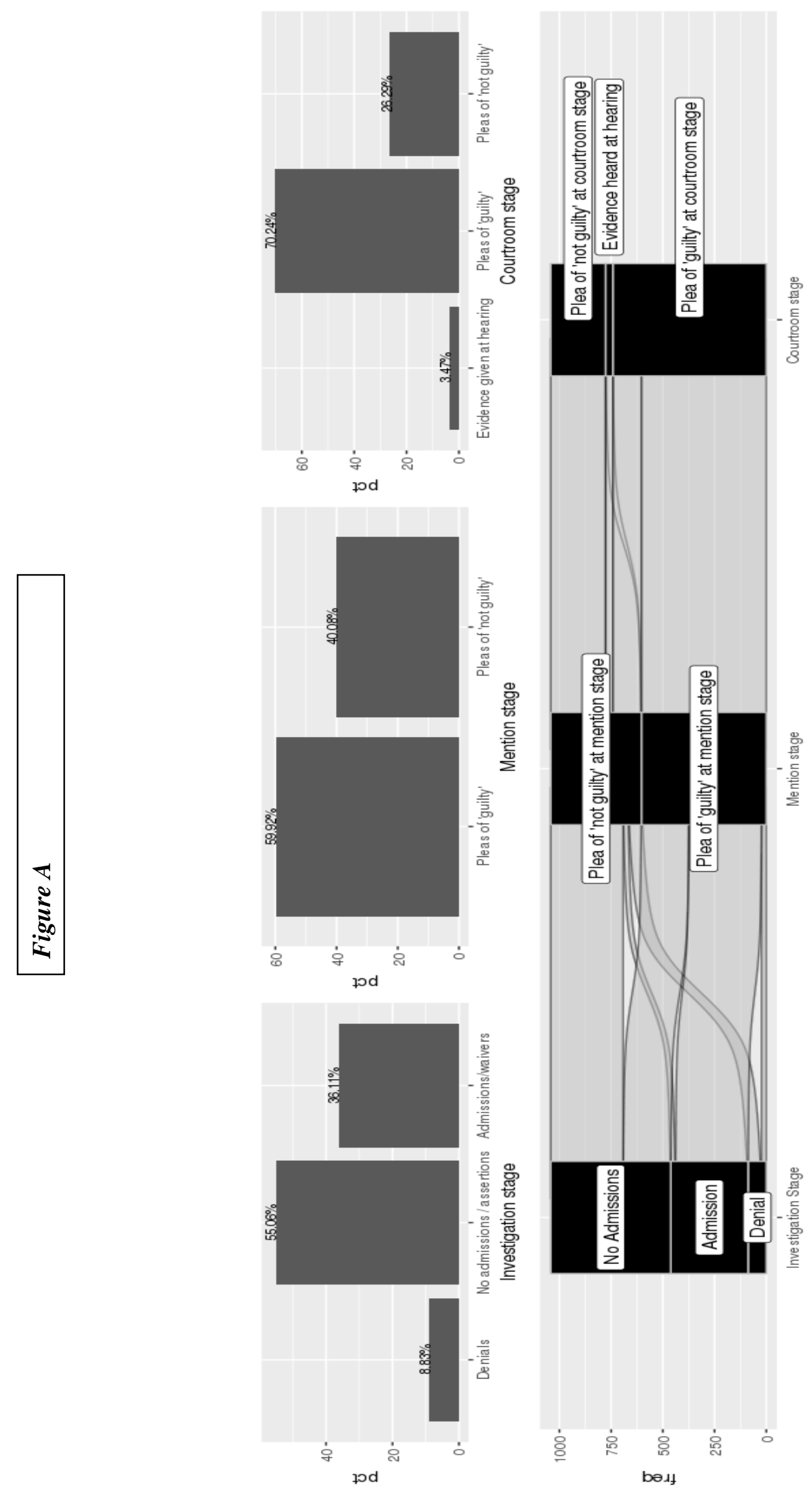




\section{Measure 2: Silence during the mention stage}

During the initial courtroom or mention stage, 604 charges $(60 \%)$ proceeded by way of 'guilty' plea, while 404 charges (40\%) remained either undecided or were subject to pleas of 'not guilty'. Undecided pleas, usually due to pending 'representations' or charge negotiation between defence and prosecution, were counted here as pleas of 'not guilty'. The shrinking number of assertions of silence rights at this stage of the criminal process is depicted in the second frequency plot in Figure A, above. The fact that a majority of charges involved a waiver of the privilege by way of 'guilty' pleas reflects and confirms official data in respect to the 'method of finalisation' (numbers of 'plea' and 'hearing' matters) in the NSW summary jurisdiction (ABS, (2019)). ${ }^{35}$ As the hackneyed adage goes, 'without guilty pleas, the wheels of justice would grind to a halt'. Confirmation of this finding also shows that the data collected here are readily generalisable and not anomalous.

\section{Measure 3: Silence during the final courtroom stage}

The number of 'guilty' pleas at the final courtroom stage of the criminal process reflects, once again, existing data on 'pleas' and 'hearings' in the NSW Summary Jurisdiction (NSW Bureau of Crime Statistics And Research (BOCSAR), (2018a)). During this stage, there was a significant change in the number of 'not guilty' pleas, with $138(14 \%)$ of these pleas (to individual charges) switched to pleas of 'guilty'. As discussed further below, this change is mostly attributable to the plea-bargaining process.

In total, 743 charges (74\%) at this stage involved 'guilty' pleas while $265(26 \%)$ proceeded by way of 'not guilty' pleas. This growth from a significant majority of assertions of silence rights at the outset of the criminal process, to an overwhelming majority of waivers of silence

35 'NSW - Method of Finalisation'. 
rights by the end of the criminal process, is a new and significant finding. It is represented within the third frequency plot in Figure A above.

\section{Measure 4: Evidence during hearing}

Defendants gave evidence during the hearing of 35 charges (3.4\%). From a total of 145 charges $(14.4 \%)$ that ran to hearing, around one quarter (24.3\%) involved defendants giving evidence (see the third frequency plot in Figure A).

\section{Measure 5: Evidence during hearing given in interview}

Of the charges in which defendants gave evidence at hearing, 14 defendants $(1.3 \%$ of all charges or $40 \%$ of charges in which defendants gave evidence at hearing) repeated the same evidence (denials) given during a police interview. This practice had a significant impact on the result of the charge, as the next section on the 'effects of the right to silence' shows. The frequency of evidence given during the hearing, also given during the interview, is plotted in the larger graph at the bottom of Figure A.

\section{Measure 6: Total assertions and waivers}

Total assertions of silence rights across all stages of the criminal process (all charges in which defendants either declined an interview or pleaded 'not guilty' or did both), numbered 627 charges $(62 \%)$. Note that this figure excludes denials. Total waivers (all charges in which defendants either made full admissions during the investigation stage, pleaded 'guilty' or gave evidence at hearing), numbered 737 charges (73\%). Note that these are overlapping variables and must be compared to each other through univariate analysis. The exclusion of denials from this analysis yields a marginally different result to that deployed during the investigation stage (by 2\%). Overall, this measure reflects existing understandings of the 
basic procedural patterns within the criminal process in which most defendants elect to plead 'guilty'. What is surprising, however, is that silence rights were asserted so frequently, in $62 \%$ of charges, at some stage throughout the criminal process.

These results are plotted on the larger graph at the bottom of Figure A. In this way, this graph provides a visual representation of the use of silence rights by defendants, over time, from the beginning of the criminal process until its conclusion. It represents the general tendency for assertions of silence rights during the investigation stage to become waivers resulting in guilty pleas.

\section{Measure 7: Consistent assertions and waivers}

In only a minority of charges did defendants both completely and consistently assert or waive their silence rights throughout the criminal process. The right to silence, burden of proof and privilege against self-incrimination were consistently and completely asserted, through a combination of no admissions, 'not guilty' pleas and silence at hearing (where matters ran to hearing) across 195 charges (19.5\%). Meanwhile, silence rights were consistently and completely waived, through a combination of full admissions and 'guilty' pleas, in 320 charges $(31.5 \%)$.

\section{Measure 8: Representations}

Nearly one third of charges (290 charges (28.9\%)) was the subject of representations or plea bargaining - 75 matters in total. In this respect, another significant finding of the study was that in order to facilitate plea or charge bargaining, defendants were required to maintain the privilege against self-incrimination until the bargain was negotiated. In only 14 out of 75 matters (18.6\% of matters) did defendants make admissions prior to the bargaining process. 
The remaining matters involved either denials (11 matters or 14.6\%) or no admissions (50 matters $(66.6 \%)$. In this sense, it appears that the right to silence and the privilege against self-incrimination, in particular, are crucial to the plea-bargaining process.

\section{Effects of the Right to Silence}

The effects of silence rights were measured here by assessing their impact on conviction. Convictions involve a finding or acceptance of a plea of guilty by a magistrate, followed by the imposition of a conviction. They are distinguished here from 'non-convictions'. In this study, non-convictions included instances when charges were laid, filed and later withdrawn by police (withdrawn charges) as well as charges resulting in a non-conviction disposition under s. 10 of the Crimes (Sentencing and Procedure) Act 1999 (NSW). Non-convictions were also recorded in this study when charges were dismissed after a finding of 'not guilty' at summary hearing. The overwhelming majority of non-conviction matters recorded here were charges that were withdrawn by police in response to a plea of 'not guilty'. The statistics evaluated in this second part of the survey show correlations between silence and conviction.

\section{Measure 1: Silence during the investigation stage resulting in conviction}

Of 453 charges in which defendants participated in a police interview or made admissions during the investigation stage (including denials), 362 (37\% of all charges or $80 \%$ of matters in which police interviews were given) resulted in conviction. Of 555 charges associated with non-interviews, by comparison, 333 of these (33\% of all charges or $60 \%$ of all non-interview matters) resulted in conviction. Accordingly, there is a statistical difference of $20 \%$ between interview and non-interview matters resulting in conviction. This correlative relationship is strengthened by the fact that between the investigation stage and the final courtroom stage, confessions or pleas of 'guilty' increased (from 453, during the investigation stage, to 743 at 
the final stage) by nearly one third (29\%). Of 110 charges in which denials were made during the investigation stage (exclusive of waivers of the right to silence by admissions), 57 (51.8\% or $5.65 \%$ of all charges) resulted in conviction, mostly through guilty pleas.

\section{Measure $4^{36}$ : Evidence given at hearing resulting in conviction}

A total of 144 charges ran to hearing. Among the 35 charges in which defendants gave evidence at hearing, 13 charges (37.14\% or $1.28 \%$ of all charges) resulted in conviction. These high rates of non-conviction associated with giving evidence at hearing appear to be associated with the repetition of a denial made during a police interview at hearing. This is explained by the following statistic discussed in Measure 5. As discussed further in the 'analysis' section below, such an association is not, on its own, determinative of conviction. As previously discussed (p. 11), such an association shows that silence rights do impact upon conviction but are also a constitutive vehicle for other trial processes or variables such as the strength of the prosecution case or the defendant's past experience of the legal system.

\section{Measure 5: Evidence given at hearing, also given in interview, resulting in conviction}

Of the 35 charges in which defendants gave evidence at hearing, 14 of these ( $40 \%$ or $1.38 \%$ of all charges) involved defendants repeating denials made during a police interview. All but one of these charges (93\%) resulted in an acquittal or dismissal of charges. Despite the numbers being small, these statistics indicate that a consistent and adamant denial of charges is the most powerful defence against any criminal accusation. In terms of silence rights this shows that in a small minority of matters, consistently waiving the right to silence from the interview stage by making a denial and maintaining this denial until the final stage of the

\footnotetext{
${ }^{36}$ Note that 'Measure 2: Silence during the mention stage' and 'Measure 3: Silence during the final courtroom stage' have been excised from comparison with effects here where the results of waiver in Measure 2 obviously result in conviction, while the results from both measures overlap with and are counted in Measures 4, 7 and 8 in the 'effects on conviction' section.
} 
criminal process (hearing), shares a compelling correlation with acquittal or dismissal of charges following the hearing. This claim must be treated with some caution, however, as it is based on a small sample of data from within the larger study and is affected by the presence of untested variables.

\section{Measure 6: Total assertions and waivers resulting in conviction}

From a total of 627 charges in which defendants asserted the right to silence at some point during the criminal process, 367 such charges resulted in conviction (36\% of all charges, or a rate of $58 \%$ of all charges in which the right to silence was asserted). Meanwhile, from a total of 737 charges in which defendants waived the right to silence at some point throughout the process, 697 resulted in conviction $(69 \%$ of all charges, or a rate of $95 \%$ of all charges in which the right to silence was waived). This marked variation in outcomes - a difference of $37 \%$ across such a large part of the sample group within this study - indicates that for the largest cohort of criminal defendants, even sporadic assertions of the right to silence were associated with significantly fewer convictions than its sporadic waiver. Sporadic waiver, by contrast, almost always correlated with conviction. These results are depicted on the graph in Figure B, below (it must be remembered that the category of 'total assertions and total waivers' contains overlapping variables). 


\section{Figure B}

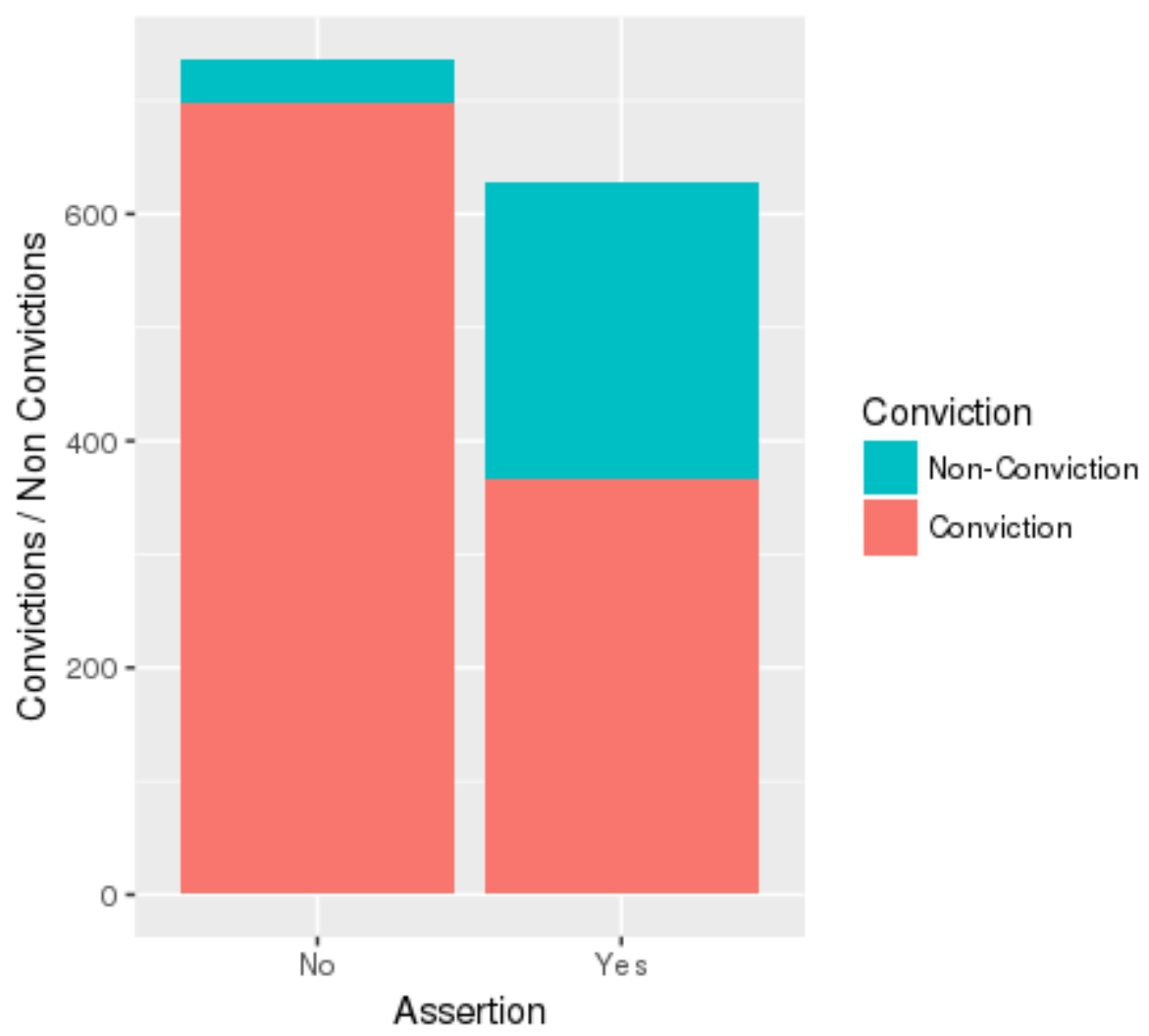

Measure 7: Consistent assertions and waivers resulting in conviction

This measure led to the most significant finding from this study. It showed that of the 195 charges where defendants consistently and completely maintained or asserted silence rights throughout the criminal process, only 27 charges correlated with conviction $(2.7 \%$ of all charges or $13.8 \%$ of all complete assertions of the privilege). Another way of putting this is that there was no conviction in $86.2 \%$ of cases in which silence was consistently asserted. Consistent waivers of the privilege, on the other hand, which occurred in 320 charges, were associated with a conviction rate of $96.3 \%$ (308 charges or $30.5 \%$ of all charges). ${ }^{37}$ This comparison is presented in the graph at Figure $C$, pictured below. The substantial difference between complete waivers and assertions of the right to silence across charges is partly

\footnotetext{
${ }^{37}$ An acquittal rate of $3.3 \%$.
} 
explained by the process of charge-bargaining, (discussed below). This measure involved standard bivariate non-overlapping categories of analysis.

\section{Figure C}

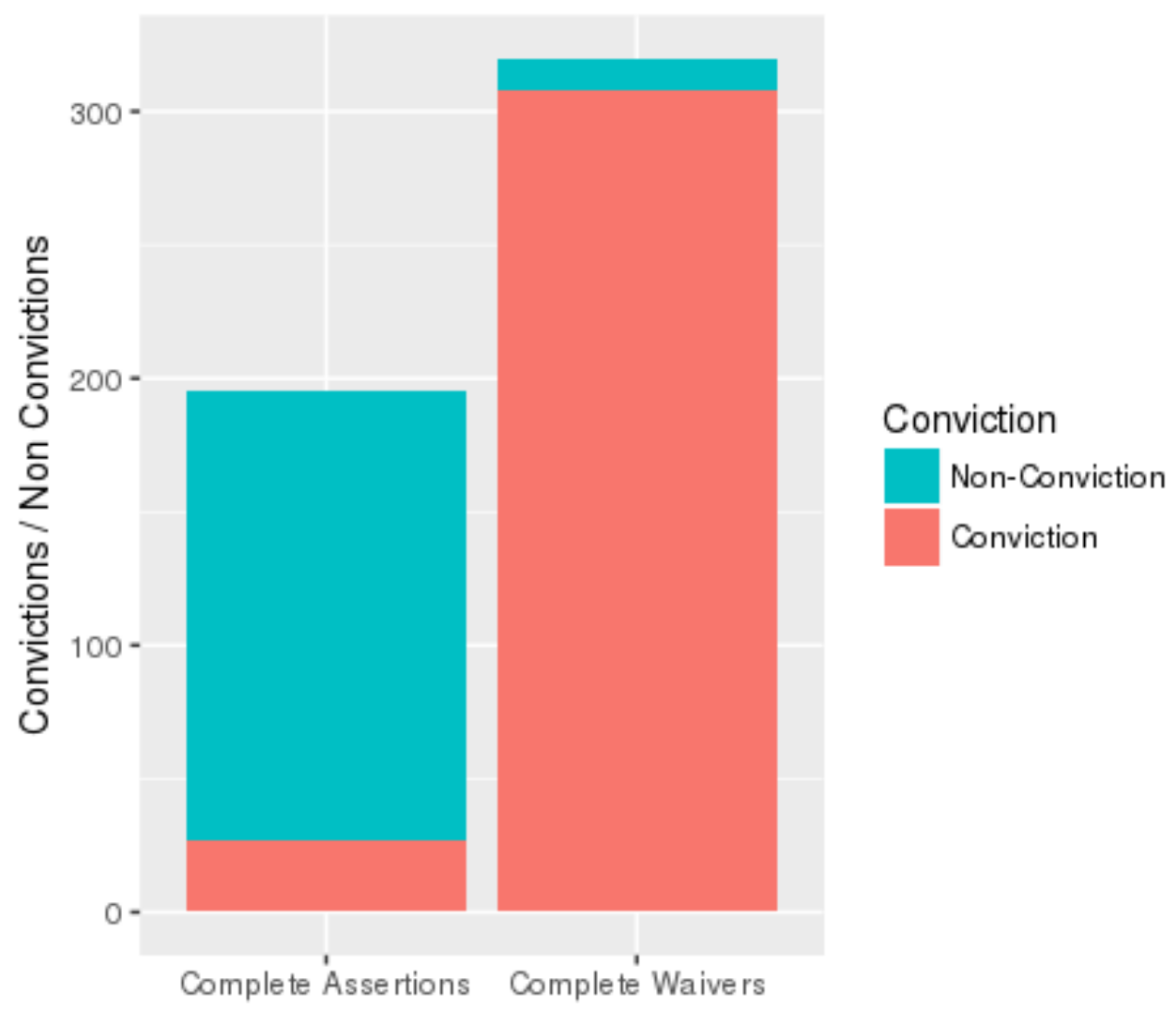

Measure 8: Representations resulting in conviction / reps resulting in amended facts / reps resulting in serious charges being withdrawn

Of the 75 matters involved in the charge bargaining process, $57(76 \%)$ resulted in charges being withdrawn by the prosecution before the final stage of proceedings. Of these matters, $46(61 \%)$ involved the withdrawal of serious charges (charges containing offences punishable by two years or more imprisonment), while 20 involved a significantly mitigating amendment of facts. In only two matters $(2.6 \%)$ in which representations were made, did the prosecution 
refuse to either withdraw charges and/or amend the facts towards a mitigated outcome for the defendant.

All matters containing representations resulted in at least one conviction. Indeed, a plea to at least one charge is usually a requirement of the plea or charge bargaining process. But just as the charge bargaining process requires the defendant to waive the burden of proof and privilege against self-incrimination in this way, the entire process of charge-bargaining appears to hinge on silence rights. Logically speaking, a bargain is rarely possible if one side capitulates from the outset. This logic is borne out by the statistics presented here and above, demonstrating that in only $18.6 \%$ of plea bargain matters did defendants waive their right to silence by making admissions before negotiations had commenced.

\section{Analysis}

Comparison with official statistics and findings from previous studies mostly shows that the data collected here was not anomalous and within the range found in previous studies, when variables in this study are accounted for. Guilty pleas in this study at the final determination stage reached $74 \%$. This is similar to the rate of guilty pleas tabled by the official statistics in this jurisdiction both in NSW and the UK (77\%) (BOCSAR, (2018b), Table 3; Crown Prosecution Service (CPS), (2019), Q1). ${ }^{38}$ The use of silence during the investigation stage sat at $55 \%{ }^{39}$ in this study, which falls within the range ${ }^{40}$ found by previous studies and is identical to the rate at which the most socially marginalised defendants in the study of

\footnotetext{
${ }^{38}$ Note that the Australian and UK statistics differ slightly by the unit of analysis measured. Australian crime statisticians predominantly measure numbers of defendants (see ABS and BOCSAR), while the statisticians in the UK (CPS and Office of National Statistics (ONA)) measure charges. Incidentally, charges were the unit of analysis used in this study.

${ }^{39}$ The figure is $64 \%$ is denials are included.

${ }^{40}$ Among studies of the right to silence, figures measuring its exercise vary between 45-60\% (Softley, (1980); Sanders, Bridges, Mulvaney, and Crozier, (1989); Moston, Stephenson and Williamson, (1993); Moston and Stephenson, (1993); Evans, (1993)).
} 
Phillips and Brown (1998) exercised the right to silence (pp. 71-73). Incidentally, this figure declined significantly to $39 \%$ in the post-adverse inference provision study of Bucke et al. (2000) and was cut in half for the most socially marginalised defendants in that study (p. 32; Owusu-Bempah (2017), pp. 133-134).

The conviction rate in this study was $70 \% .^{41}$ The official conviction rate in this jurisdiction is 91\% (BOCSAR, (2018b)). Variance between these figures is probably attributable to comparatively fewer strict liability traffic matters within the Legal Aid sample. Traffic matters account for $40 \%$ of matters in this jurisdiction (ABS, 2019). Without traffic matters, the conviction rate from this study more closely resembles that found in indictable courts in both NSW and the UK (72-85\%) - courts which do not regularly hear traffic matters. ${ }^{42}$ When the absence of traffic matters is accounted for, it may be that the minor variance in conviction rates between these jurisdictions (between 2-15\%) is also related to the absence of adverse inference provisions in this jurisdiction. Clearly, these results differ from those of Buck et al. (2000) which show that adverse inference provisions have nil effect on conviction rates (p. 66). Instead, conviction rates in this study might be seen as supporting the view of Redmayne (2008): that adverse inference provisions probably have some effect but one that is partly indeterminate due to the presence of other variables (pp. 1081-1083). But this study was not exclusively focused on the effect of adverse inference provisions and its findings have wider implications for understanding the general operation of silence rights.

\footnotetext{
${ }^{41}$ The fact that the conviction rate is less than the number of guilty pleas is attributable to the high number of dismissals of charges in this jurisdiction that occur during $17 \%$ of all sentencing hearings (Attorney General and Justice NSW, (2011), p. 28).

42 The conviction rate in these higher courts has, for the last five years fluctuated between around $72-85 \%$ (see BOCSAR, (2018a) and CPS (2019).
} 
The most significant and new findings from this study arose from the measurement of silence use and its effects over time in periodic stages throughout the criminal process. Such an approach showed that there is a correlation between consistent or complete assertions of the right to silence (consistently maintaining silence throughout the criminal process) and lower rates of conviction. ${ }^{43}$ As Figure $C$ shows, $86.2 \%$ of consistent assertions of the right to silence (168 charges) were associated with acquittals or the equivalent, compared with only $3.3 \%$ of consistent waivers (12 charges). Further, as shown by Figure B, assertions of the right to silence generally had more favourable results and were associated with substantially fewer convictions than waivers of silence rights. Defendants were: $20 \%$ less likely to be convicted after exercising silence rights in the investigation stage; $37 \%$ less likely to be convicted after exercising silence rights sporadically throughout the entire process (compared to sporadic waiver); and $82.5 \%$ less likely to be convicted as a result of completely or consistently asserting silence rights (compared to its consistently waiving them).

Placed in context, these findings mean that for a majority of marginalised defendants, there may be a tactical or strategic advantage to the exercise of silence rights in the type of cases surveyed here (i.e. non-regulatory summary matters). However, it must be remembered that these results are affected by other variables such as the strength of the evidence, experience with the criminal justice system and, to a lesser degree, the seriousness of the charge (Phillips and Brown, (1998), p. 74). In this way, silence rights might be seen as a processual vehicle through which other variables are expressed. But, as explained above by reference to the work of Stewart (2016) and Bucke et al. (2000), there is empirical value in measuring and

\footnotetext{
${ }^{43}$ When subjected to a Pearson's Chi-Squared Test of the null hypothesis that there is no association between assertion type and conviction, the results were as follows: $\chi 2=358.27, \mathrm{df}=1, \mathrm{p}<0.001$. A $\mathrm{p}$-value of less than 0.001 resulted from a comparison with a chi-squared distribution with one degree of freedom. Taken at a standard or accepted level of error of 0.05 , the null hypothesis that there is no association between assertion and conviction can be safely rejected. Ipso facto, it can be concluded that there is an association between assertions and conviction.
} 
understanding how silence is exercised and operates, particularly where understandings of its operation are contested and where no published empirical studies have measured its operation in this jurisdiction.

It is noted that this study did not measure the use of silence rights by non-marginalised defendants. Nevertheless, the larger studies of Phillips and Brown (1998) and Bucke et al (2000), do provide some measure of comparison between silence use between various social groups, as does a comparison between the statistics produced by this study and the official English and NSW statistics, discussed above (pp. 28-29). ${ }^{44}$ It is on the basis of these statistical differences that this study has been reluctant to draw wider generalisations or inferences about the use of silence rights by all summary criminal defendants (i.e. nonmarginalised criminal defendants), other than those sampled within the discrete dataset used in this study. Accordingly, caution has been exercised in this analysis, restricting observations to the experience of the marginalised defendants who were the subjects of this study. In this important respect, this study provides the basis for further comparative analysis.

The results from Measure 5B add nuance and further explanation to the above findings. They show that when silence is used in a very specific but consistent way - by denying the charge at the investigation stage and repeating this denial in evidence at hearing (waiving the right to silence and privilege against self-incrimination while asserting the burden of proof) - it is associated with even lower rates of conviction than complete assertions of the silence rights (in $93 \%$ or 13 out of 14 charges of these charges). Nevertheless, the fact that this specific combination of practices of consistently denying the charge occurred in so few charges (14

\footnotetext{
${ }^{44}$ It must also be remembered that the marginalised client base represented by Legal Aid NSW account for around $57 \%$ of the NSW summary court population (see p. 10 and Footnote 23).
} 
charges or $1.4 \%$ of charges) means that any association between this practice with rates of conviction borders on statistical insignificance, requiring a further and much larger study to assess its significance. ${ }^{45}$ One suggested implication of this finding, however, is that waiving the right to silence and privilege against self-incrimination or repeating the evidence from the interview at hearing, favours defendants who are either emphatically innocent or able to maintain a consistent and coherent defence throughout the criminal process. But the minimal amount of data collected in support of this contention shows that legally aided criminal defendants who possess these characteristics are certainly in the minority. Accordingly, this variation in the findings supports the tentative conclusion, drawn above, that the association between silence rights and conviction means that silence rights are procedurally important, ensuring fairness for marginalised defendants throughout the criminal process. For a majority of summary criminal defendants who are perhaps not able to craft and maintain a sophisticated 'denial' of allegations, silence rights are the only realistic, effective and fair option to protect innocence against false accusations of guilt.

This secondary result involving the waiver of silence rights further shows that other factors such as the strength of the evidence and experience with the criminal justice system, have a role to play in the way that silence rights are exercised. To be clear, while silence rights share an association with conviction, they do not, on their own, determine conviction. They are an important factor or vehicle by which other factors, such as the strength of the evidence, experience within the legal system and so on are played out and expressed. To what extent these other factors play a role in the exercise of silence rights remains unclear but the

\footnotetext{
${ }^{45}$ When analysed by way of a chi-squared test (a null hypothesis that there is no association between waivers and non-convictions) the p-value (resulting from the number of denials) was slightly below ' 1 '. Supposing an accepted level of error of 0.05 , these results suggest that there is not enough data available to make a definitive conclusion. Accordingly, the null hypothesis that there is no association between waivers and convictions still stands.
} 
tangential observations of the sample in this study are illuminating. In previous studies, the provision of legal advice played a major part in a defendant's decision to exercise silence rights at the police station (Phillips and Brown, (1998), p. 72; Sanders et al. (1989); Moston, Stephenson and Williamson, (1992)), yet none of the defendants surveyed here accessed a lawyer during the investigation period and most exercised the right to silence upon arrest. In other studies, stronger evidence of an offence corresponded with more frequent admissions (Phillips and Brown, (1998), p. 72-76; Sanders et al. (1989); Moston, Stephenson and Williamson, (1992)). Those results seem to have been confirmed here with a greater likelihood of admissions in cases with CCTV footage and independent eyewitness statements. A more detailed appraisal of the role of these other factors in the exercise of silence rights, however, is beyond the scope of this study, requiring further research.

These findings on the significance of silence rights also had important ramifications for the process of charge-bargaining. This study found that the right to silence was exercised in significantly higher proportions during the process of charge-bargaining (across $81.4 \%$ of charge-bargaining matters - see Measure $8 A$ ). As a matter of logic, charge negotiation would be substantially impaired if defendants disclosed their case or confessed to all charges in their case prior to commencing the negotiation process. That admissions reduce the bargaining power of defendants is confirmed by the statistical data presented here showing that strong and frequent assertions of silence rights during the investigation and mention stages are integral to the process of charge-bargaining. Measure $8 B$ shows that preservation of silence rights by defendants during the investigation stage was associated with a negotiated outcome of the matter, leading charges to be withdrawn in $76 \%$ of charge-bargaining matters. The assertion of silence rights during the investigation stage appears to facilitate the charge negotiation process. This has crucial relevance to NSW lawmakers, particularly where the 
NSW Parliament has passed two pieces of legislation within the last five years seeking to encourage charge-bargaining. ${ }^{46}$ What these data and analysis suggest is that in order for parties to reach a negotiated outcome, as encouraged by the State, silence rights must be protected and strengthened.

The key finding that silence rights are associated with conviction outcomes poses an intriguing question for the results of previous studies showing that there is no causal link between the watering-down of silence rights (for instance, through adverse inference provisions) and the overall conviction rate. As stated at the outset, this study does not seek to challenge those findings. Rather, the results from this study have sought to explain data that resembles a cross-section of results from larger studies in order to shed light on unresolved questions that they pose. In the process, this study revealed new evidence about the workings of silence rights in an Australian summary jurisdiction.

Key findings on the use and effects of silence rights by marginalised criminal defendants in mostly non-regulatory matters in the summary jurisdiction of NSW may be summarised as follows:

- The right to silence is exercised most frequently during the investigation stage of the criminal process in 55\% of charges (about the same rate as the exercise of those rights by comparable defendants in the comparable jurisdiction of the UK, prior to the introduction of adverse inference provisions).

\footnotetext{
${ }^{46}$ See the, Criminal Procedure Amendment (Pre-Trial Defence Disclosure) Act 2013 (NSW); and the Justice Legislation Amendment (Committals and Guilty Pleas) Act 2017 (NSW).
} 
- Silence rights have an association with conviction (obviously, at the mention stage when its waiver by guilty plea most commonly results in conviction, ${ }^{47}$ but also) when exercised consistently throughout the criminal process.

- Consistent exercise of silence rights throughout the criminal process occurred in $17 \%$ of charges and correlating with more acquittals (86.2\%) than their inconsistent exercise or waiver. ${ }^{48}$

- Consistent denials of the charge (mixing the waiver of the right to silence and privilege against self-incrimination with an assertion of the burden of proof) occurred in $1.5 \%$ of charges, correlating with a high proportion of aquittals (93\%).

- Silence rights are asserted in $81 \%$ of charge-bargaining matters, appearing to assist negotiated outcomes in which a plea of guilty to at least one charge was exchanged for withdrawal of at least one charge.

\section{Conclusion}

In measuring silence rights in this jurisdiction, it is possible to say that silence is associated with conviction for marginalised defendants in certain matters. That is, silence matters for the most marginalised people in the criminal justice system. Consistent assertions of silence rights for this group of defendants share an association with non-conviction. In a few discrete cases, it is possible that the consistent and deftly used waiver of the right to silence to deny criminal allegations, can result in a more thorough routing of the prosecution case than a consistent assertion of silence rights. Nevertheless, the weight of evidence examined here suggests that consistent assertions of silence, rather than consistent waiver by denial of charges, is more frequently associated with non-conviction for this group of defendants. In

\footnotetext{
${ }^{47}$ Although, the court nevertheless maintains discretion to impose no conviction (under the Crimes (Sentencing Procedure) Act 1999, s. 10) and in fact, the disparity between the rate of guilty pleas (74\%) and convictions (70\%) illustrates this discretion.

${ }^{48}$ This category excludes denials.
} 
addition, silence rights appear to play a role in the smooth and efficient operation of criminal process, in particular, the process of plea-bargaining.

These findings have other ramifications requiring further analysis. First, there is some support for the claim that adverse inference provisions in the indictable jurisdiction of NSW do have some effect - albeit a small one - on increased conviction rates, when compared with the results in this jurisdiction. A comparative study in that jurisdiction, reliant on the present findings, may provide an answer. Second, it remains to be seen whether alteration of silence rights by powers of compulsory interview, such as those possessed by regulatory agencies, have any impact on rates of conviction when compared with the results of this study. Again, a further comparative study in one or more of these regulatory jurisdictions that relies on the present findings, may prove useful here. And third, the findings of this study relating to use of silence rights by specifically marginalised defendants would be bolstered by a further and similar study on the exercise of silence rights by non-marginalised criminal defendants in the summary jurisdiction of NSW.

The results of this study, by shining further light on the relationship between use of silence rights and their effect on conviction for socially marginalised defendants in non-regulatory summary offences, suggest that silence rights are a critical democratic right for this constituency. Paradoxically, perhaps, silence rights may be understood as permitting marginalised criminal defendants to 'have a say' over their destiny. However, this implication requires further paths of inquiry for its establishment: i) a qualitative analysis of relevant case law; and ii) a theoretically-informed analysis and discussion of the findings from this study. At stake here is a concern voiced by Australian 'critical realist' criminologist, Robert Hogg (1987), who cautioned that 'there is an enormous potential for' truthful criminology 'to be 
politically harnessed in a conservative direction' (pp. 136-137), such as by extending adverse inference provisions or introducing further measures of compulsion against marginalised defendants. Against such reactionary politics, Hogg (1987) encouraged policy makers, lawyers and criminologists to continue to reveal data but to confront it by continuing to democratise criminal process for those subject to it, advocating 'coherent (social) programs, and strategies' (pp. 136-137), rather than restrictions on democratic processes. Hence, it is imperative to elaborate from these findings further through a more detailed theoretical and qualitative analysis. 


\section{References:}

Aronson, M., \& Hunter, J. (1995). Litigation, $5^{\text {th }}$ Edition, Sydney: Butterworths.

Attorney General and Justice NSW. (2011). Good Behaviour Bonds and Non-Conviction Orders: A report of the NSW Sentencing Council. Sydney: NSW Sentencing Council.

Australian Bureau of Statistics (ABS). (2019). Criminal Courts 2017-2018. 4513.0, Canberra.

Australian Law Reform Commission. (2016). Traditional Rights and Freedoms. Report No 129, Sydney.

Birch, D.J. (1999). Suffering in Silence: A Cost-Benefit Analysis of Section 34 of the Criminal Justice and Public Order Act 1994. Criminal Law Review, 769-788;

Bryman, A. (2016). Social Research Methods. Oxford: Oxford University Press.

Bucke, T., Street, R., \& Brown, D. (2000). The right of silence: the impact of the Criminal Justice and Public Order Act 1994. London: Home Office (UK).

Coldrey, J. (1991). The Right to Silence: Should it be Curtailed or Abolished?. AngloAmerican Law Review, 20, 51-62.

Comino, V. (2014). James Hardie and the Problems of the Australian Civil Penalties Regime. UNSW Law Journal, 37(1), 195-207.

Crown Prosecution Service (CPS). (2019). Key Performance Indicators, Q1, 2017-18, Retrieved from https://www.cps.gov.uk/key-measures (accessed 17 April 2019).

Cross, R. (1970-71). The Right to Silence and the Presumption of Innocence: Sacred Cows or Safeguards of Liberty?. Journal of the Society of Public Teachers of Law, 11, 66-79.

Dennis, I. (1995). The Criminal Justice and Public Order Act 1994: The Evidence Provisions, Criminal Law Review, 4-18;

Dixon, D., \& Cowdery, N. (2013). Silence Rights. Australia Indigenous Law Review, 17(1), 23-37.

Duff, R.A. (2007). Answering for Crime: Responsibility and Liability in the Criminal Law, Oxford: Hart Publishing.

Evans, R. (1993). The Conduct of Police Interviews with Juveniles. Royal Commission on Criminal Justice (UK), Research Study No. 8, London.

Gotsis, T., \& Donnelly, H. (2008). Diverting mentally disordered offenders in the NSW Local Court. Sydney: NSW Judicial Commission.

Grant, T (M.P., former NSW Justice Minister). (2018). Political campaign statement, Troy Grant M.P.. Retrieved from http://www.troygrant.com.au/troys-column/right-to-silence (accessed 29 August 2018). 
Heydon, J.C. (2018). Cross on Evidence. Sydney: Lexis Nexis.

Hocking, B., \& Manville, L.L. (2001). What of the right to silence: Still supporting the presumption of innocence, or a growing legal fiction?. Macquarie Law Journal, 3, 63-75.

Hogg, R. (1987). Review Essay: Left Realism and Criminology. Australian Journal of Law and Society, 4, 128-147.

Honneth, A. (1996). The Struggle for Recognition: Moral Grammar of Social Conflicts, Cambridge: Polity Press.

Jackson, J. D., Kilpatrick R., \& Harvey, C. (1991b). Called to Court: A Public View of Criminal Justice in Northern Ireland. Belfast: S.L.S. Publications.

Jackson, J., Quinn, M., \& Wolfe, K. (2000). Legislating Against Silence: The Northern Ireland experience. Belfast: Northern Ireland Office (UK).

Jackson, J.D. (1991). Curtailing the Right to Silence: Lessons from Northern Ireland. Criminal Law Review, 6, 404-415.

Jackson, J.D. (2001). Silence and Proof: Extending the Boundaries of Criminal Proceedings in the United Kingdom. International Journal of Evidence and Proof, 5, 145-173.

Lacey, N. (2012). Principles, policies, and politics of criminal law. In L. Zedner \& J.V. Roberts (Eds.), Principles and Values in Criminal Law and Criminal Justice: Essays in Honour of Andrew Ashworth (pp. 19-36). Oxford: Oxford University Press.

Legal Aid NSW. (2018). Annual Report, 2016-2017, Sydney.

Legal Aid NSW. (2018). Means Test, Retrieved from https://www.legalaid.nsw.gov.au/forlawyers/policyonline/policies/7.-means-test (accessed 27 August 2018).

Leng, R. (1993). The Right to Silence in Police Interrogation: a study of some of the issues underlying the debate. Royal Commission on Criminal Justice Research Study (UK) No. 10, London.

Moston, S., \& Stephenson, G. (1993). The Questioning and Interviewing of Suspects outside the Police Station (Royal Commission on Criminal Justice (UK), Research Study No. 22, London 1993).

Moston, S., Stephenson, G., \& Williamson, T. (1993). The incidence, antecedents and consequences of suspects' use of the right to silence. Criminal Behaviour and Mental Health, $3(1), 30-47$.

NSW BOCSAR. (2018a). Outcome of NSW Criminal Court Appearances: 2017, Criminal Court Statistics 2017, Retrieved from https://www.bocsar.nsw.gov.au/Pages/bocsar_court_stats/bocsar_court_stats.aspx (accessed 15 April 2019). 
NSW BOCSAR. (2018b) NSW Higher, Local and Children's Criminal Courts, Jan 2017-Dec 2017, Table 3, NSW Local Court, Criminal Court Statistics 2017, Retrieved from https://www.bocsar.nsw.gov.au/Pages/bocsar_court_stats/bocsar_court_stats.aspx (accessed 15 April 2019).

O'Mahony, P. (1997). The ethics of police interrogation and the Garda Siochana. Irish Criminal Law Journal, 6, 129-40.

Odgers, S. (2018). Uniform Evidence Law, $13^{\text {th }}$ Edition, Pyrmont (Australia): Lawbook Co.

Owusu-Bempah, A. (2017). Defendant Participation in the Criminal Process. New York: Routledge.

Phillips, C., \& Brown, D. (1998). Entry into the criminal justice system: a survey of police arrests and their outcomes. London: Home Office (UK).

Redmayne, M. (2007). Rethinking the Privilege Against Self-Incrimination. Oxford Journal of Legal Studies, 27(2), 209-232.

Redmayne, M. (2008). English Warnings. Cardozo Law Review, 30(3), 1047-1088.

Sanders, A., Bridges, L., Mulvaney, A., \& Crozier, G. (1989). Advice and Assistance at Police Stations and the 24-hour Duty Solicitor Scheme. London: Lord Chancellor's Department.

Silver, H. (1994). Social Exclusion and Social Solidarity: Three Paradigms. International Labour Review, 133(5-6), 531-78.

Smith, G (MP, former NSW Attorney-General). (2013). Second Reading Speech re Evidence Amendment (Evidence of Silence) Bill 2013 and Criminal Procedure Amendment (Pre-Trial Defence Disclosure) Bill 2013. Hansard - Parliament of NSW, 13 March, 2.

Softley, P. (1980). Police Interrogation: an observational study in four police stations. London: Home Office (UK) Research Study No. 61.

Stewart, H. (2016). The privilege against self-incrimination: reconsidering Redmayne's rethinking. International Journal of Evidence and Proof, 20(2), 95-102.

Tan, A.K-J. (1997). Adverse inferences and the right to silence: re-examining the Singapore experience. Criminal Law Review, 471-481.

Victorian Parliamentary Scrutiny of Acts and Regulations Committee. (1999). The Right to Silence, Final Report. Melbourne.

Yeo, M. H. (1983). Diminishing the Right to Silence: The Singapore Experience. Criminal Law Review, 2, 89-101. 